\title{
Practise makes perfect: developing critical thinking and effective writing skills in undergraduate science students
}

\section{Sarah K. Hall}

School of Biosciences, Cardiff University, Museum Avenue, Cardiff CF10 3AX, UK

\begin{abstract}
Successful undergraduate students are required to demonstrate critical thinking and effective writing skills in their final year project dissertation, but the early years of some science degree programmes may not fully prepare them for this challenge. This study investigated the value of earlier engagement with scientific literacy skills by assessing the impact of rehearsing critical thinking and extended scientific writing tasks earlier in the degree programme. This paper reports a small-scale case study of a single cohort of students on B.Sc. (Hons.) Biomedical Sciences degree schemes at a research intensive university and describes quantitative analysis of students' performance in two research-driven writing tasks at different stages of the degree: a literature review in Year 2 and a research dissertation in the final year. The results of this study support the concept that earlier exposure to extended writing tasks requiring scientific literacy skills is beneficial for students whose final year project has a similar literature-based format; the experience of completing the literature review appears particularly valuable in improving the academic performance of weaker students.
\end{abstract}

Keywords: scientific literacy; undergraduate; bioscience; writing; dissertation; practice 


\section{Introduction}

Most undergraduate students are expected to write a dissertation during the final year of their degree programme; the perceived pedagogic value of this task encompasses development of independent learning characteristics that require deep learning approaches. A student's successful demonstration of higher-order cognitive skills (such as critical evaluation and synthesis of ideas) is embedded in, and evidenced by, their written dissertation. For science students, in particular, the final year dissertation may represent the longest and most complex piece of writing they undertake during their undergraduate degree. Scientific literacy encompasses skills of interpreting, evaluating and communicating scientific evidence; such skills are recognised as important attributes by employers, course tutors and students alike. Bioscience employers rate 'written communication' above other general skills, including numeracy and other core skills (Saunders \& Zuzel, 2010) and course tutors recognise scientific and critical analytical writing skills as important outcome measures for Life Sciences degrees (Rosenfeld, Courtney \& Fowles, 2004; Marbach-Ad \& Aviv-Elyashiv, 2005). Biosciences students themselves also perceive effective writing to be an important component of their skill set; however, diagnostic tests in early years at university indicate that the writing skills of the undergraduate Biosciences student population are weak (Marbach-Ad \& Aviv-Elyashiv 2005; Jones, 2011). The reduced emphasis on extended writing in the school curriculum and, increasingly, in the early stages of undergraduate degree programmes mean that writing opportunities may be limited (Kellogg \& Whiteford, 2009), so students may be unprepared for extended writing tasks.

Inquiry-based learning activities, such as literature reviews and research projects, can improve undergraduate students' scientific literacy (Gormally et al., 2009) and such extended writing tasks can develop deeper approaches to learning (James, 1998). The specific aim of this study was to investigate the impact of undertaking an extended scientific writing task at an earlier stage of the degree programme; this task offers students prior experience of many of the advanced critical thinking and scientific writing skills that are important for success in the final-year research dissertation. 


\section{Methods}

A small-scale case study of a single cohort of undergraduate students on B.Sc. (Hons.) Biomedical Sciences degree schemes was undertaken at a research-intensive University in the U.K. Data were collected relating to two modules assessed primarily through production of an extended written report. 32 students on Biomedical Schemes completed both a literature review module (Regulated Qualifications Framework (RQF) level 5) in the second year of their degree and the project dissertation (RQF level 6) in the final year of their degree (module details in Table 1). Individual students' prior writing experience was not considered, although all students had a common learning experience in the first year of their degree schemes.

Table 1. Details of the two modules forming the focus of this study

\begin{tabular}{lcc}
\hline Module name & LITERATURE REVIEW & PROJECT DISSERTATION \\
RQF level & 5 (Year 2) & 6 (Final Year) \\
Report word limit & 4000 words & 7000 words \\
Module weighting & 20 credits & 40 credits \\
& $8.3 \%$ of year 2 & $25 \%$ of final year \\
& $1.7 \%$ of final degree overall & $20 \%$ of final degree overall \\
\hline
\end{tabular}

Academic performance data from the literature review module and the final-year project dissertation module were compared. The final-year project dissertations reported practical or library-based research activities. Projects were allocated according to students' choice and academic performance; only those students with a weighted average mark $>52 \%$ at level 5 were allocated a practical project, although students above this standard could undertake a literature-based project if they so wished. The same cohort of 32 students completed the literature review module and the final-year project dissertation module; of these, 13 completed literature-based projects and 19 completed practical projects. The marking criteria for both modules addressed the students ability to discuss and critically evaluate the research evidence (generating a component mark for the student's interaction with their supervisor) and to present their thoughts and arguments lucidly and concisely in written form (generating a component mark for the written report).

Descriptive statistics demonstrated that all data sets were normally distributed, so standard parametric tests (paired or unpaired Students t-tests, as appropriate) were used to test for significant differences between groups. 


\section{Results and Discussion}

When both practical and literature-based research projects were considered together, there was no significant difference in the average performance for the literature review module and the final year dissertation modules (Table 2; $>>0.1$, paired t-test, $n=32$ ). Furthermore, when the written report components of these modules were considered alone, the average marks were similar $(64.1 \pm 7.9 \%$ c.f. $64.3 \pm 8.2 \%$; $>0.1$, paired t-test $)$, confirming that effects on other assessment components had not masked any potential improvement in writing skills. This initial result is surprising, as regular reading and writing tasks have been shown to improve science students' academic literacy (Parkinson et al., 2008) and tutor feedback has been suggested to aid development of academic writing skills (Court, 2014). Separate comparisons of marks in relation to practical and library-based projects, however, revealed some interesting differences (Table 2).

Table 2: Comparison of the same students' performance in the Year 2 Dissertation module and the Final Year Project module.

\begin{tabular}{ccccc}
\hline & $\begin{array}{c}\text { Mean mark } \\
(\%)\end{array}$ & $\begin{array}{c} \pm \text { standard } \\
\text { deviation }\end{array}$ & Range (\%) & $\begin{array}{c}\text { Paired } \\
\text { t-test }\end{array}$ \\
\hline ALL PROJECTS $(n=32)$ & & & & \\
Yr 2 literature review & 64.4 & 8.2 & $46.6-75.3$ & $\mathrm{p}>0.05$ \\
$\quad$ Final year project & 66.5 & 8.8 & $45.1-80.3$ & $($ n.s. $)$ \\
LITERATURE-BASED PROJECTS $(n=13)$ & & & \\
Yr 2 literature review & 57.2 & 7.3 & $46.6-70.7$ & $\mathrm{p}<0.02$ \\
$\quad$ Final year project & 65.0 & 6.9 & $49.3-78.7$ & \\
PRACTICAL PROJECTS $(n=19)$ & & & \\
Yr 2 literature review & 68.5 & 5.9 & $57.3-74.8$ & $\mathrm{p}>0.05$ \\
$\quad$ Final year project & 67.5 & 9.3 & $45.1-80.3$ & $($ n.s. $)$ \\
\hline
\end{tabular}

$41 \%(13 / 32)$ of students who completed the literature review module in Year 2 also undertook a library-based project in their final year. The average academic performance of these students was significantly weaker than those doing practical projects (Table 2). The average Yr 2 literature review mark for students who went on to complete a practical project was $68.5 \pm 5.9 \%(n=19)$, compared to $57.2 \pm 7.3 \%(n=13)$ for students who went on to complete a library project ( $\mathrm{p}<0.02$; unpaired t-test). This finding might be expected, since students with lower academic performances in Year 2 were constrained to undertake library-based projects in the final year of their degree. However, the performance of these students recovered in the final year, so that there was no significant difference between the average marks for practical and library-based project dissertations (Table 2; p >0.1; unpaired t-test). These data reveal a clear improvement in this group's performance in the 
second extended writing task i.e. the final year project dissertation. The performance improved from $57.2 \pm 7.3 \%(n=13)$ in the Year 2 module, to $65.0 \pm 6.9 \%$ in the final year project module (Table 3). This significant increase in the average mark for the project $(\mathrm{p}<0.02$, paired t-test) represents an average improvement of $6.6 \%$. This improved performance supports the proposal that progressive tasks requiring the same set of skills allow students to hone their skills (James, 1998), and that this may be particularly beneficial for weaker students.

Table 3: Comparison of the overall performance of students who completed literature-based final year projects and their marks for individual components of the modules $(n=13)$.

\begin{tabular}{|c|c|c|c|c|}
\hline & $\begin{array}{c}\text { Mean mark } \\
(\%)\end{array}$ & $\begin{array}{c} \pm \text { standard } \\
\text { deviation }\end{array}$ & Range (\%) & $\begin{array}{c}\text { Paired } \\
\text { t-test }\end{array}$ \\
\hline \multicolumn{5}{|c|}{ FINAL LITERATURE-BASED PROJECT MARK OVERALL } \\
\hline Yr 2 literature review & 57.2 & 7.3 & $46.6-70.7$ & $\mathrm{p}<0.05$ \\
\hline Final year project & 65.0 & 6.9 & $49.3-78.7$ & \\
\hline \multicolumn{5}{|c|}{ MARK FOR WRITTEN REPORT COMPONENT } \\
\hline Yr 2 literature review & 58.1 & 6.7 & $46.3-70.0$ & $\mathrm{p}<0.05$ \\
\hline Final year project & 64.2 & 9.5 & $53.0-82.1$ & \\
\hline \multicolumn{5}{|c|}{ MARK FOR INTERACTION WITH SUPERVISOR } \\
\hline Yr 2 literature review & 58.2 & 11.7 & $44.0-78.0$ & $\mathrm{p}<0.05$ \\
\hline Final year project & 69.0 & 10.9 & $52.8-88.0$ & \\
\hline
\end{tabular}

The final mark of both modules was composed of independent marks for the written report component and the supervisor's assessment of the students ability to participate in discussion and critical evaluation of the research topic. Considering the written report component of the assessments only, there was also a significant improvement in these students' marks between the two writing tasks (Table 3; $\mathrm{p}<0.05$, paired t-test); the average mark increased from $58.1 \pm 6.7 \%$ to $64.2 \pm 9.5 \%$, with an average improvement of $6.1 \%$. It has been shown previously that weaker students are most likely to benefit from practising scientific literacy skills (Parkinson et al., 2008), and that repetition of contextual writing tasks can be particularly beneficial to weaker students (Johnstone et al., 2002). However, this improvement in the written component does not solely explain the increased module mark overall. The average marks for the supervisors' assessment of students' ability to participate in critical discussions also increased significantly (from $58.2 \pm 11.7 \%$ to $69.0 \pm 10.9 \%$; $<<0.05$, paired t-test) between the two modules (Table 3). Tutor marks have been shown to correlate positively with evidence of deeper approaches to learning, including critical thinking / analytical inquiry (Cassidy, 2006). More direct assessment of such skills remains complex and challenging (Liu et al., 2014), but these data suggest a key role of the tutor in developing critical thinking skills of weaker students, in particular. 
Students who chose practical projects achieved similar average marks in their literature review module and the project dissertation (Table 2; $>0.1$, paired t-test). Similarly, there was no difference in the mark for the written component alone ( $p>0.1$, paired t-test). In contrast to the students undertaking literature-based projects, these data do not demonstrate any clear improvement in performance following completion of the literature review module in Year 2; there are a number of possible explanations for this. Students undertaking the practical project tended to have a better final mark in the literature review module (Table 2; $\mathrm{p}<0.05$, unpaired t-test), suggesting that these students may have refined their deep learning and writing skills during this Year 2 module, before starting their final year project module, so that no further improvement was apparent. Alternatively, since the practical projects also require students to develop specialised experimental techniques and data analysis skills, these students may fail to apply their skills in this different context (Stefani et al., 1997; Scott, 2005). It should also be acknowledged that multiple complex factors, including motivation, competitiveness and mastery goals, may contribute to an individual's performance in assessments of higher learning (Harackiewicz et al., 2002), and that these influences may not be equal in both groups of students.

\section{Conclusions}

The results of this small-scale study support the concept that earlier exposure to tasks requiring advanced scientific literacy skills benefits those students whose final year research project activities closely model the template of a literature review; the experience of rehearsing these skills appears particularly valuable in improving the academic performance of weaker students. These findings provide the foundation for a more extensive longitudinal study of progression through the full degree programme; this would allow deeper insight into the ways that extended writing tasks foster higher-order cognitive skills, and more comprehensive evaluation of the relative benefits to different sub-sets of the student population. Furthermore, the central role of the tutor in this academic process should also be recognised, and it would be useful to evaluate in more detail the contribution of individual student-tutor interactions in academic tasks requiring problem-solving, critical thinking and effective writing. Information from these studies is likely to further demonstrate the value of including tutor-led extended scientific writing tasks at all stages of the degree programme; however it should be recognised that the pressures of increasing student numbers (and associated reductions in staff-student ratios) may challenge the provision of such individualised, interactive learning experiences. 


\section{References}

Cassidy, S. (2006) 'Learning style and self-assessment skill' Education and Training 48(2); 170-177

Court, K. (2014) ' Tutor feedback on draft essays: developing students' academic writing and subject knowledge' Journal of Further and Higher Education 38(3); 327-345

Gormally, C.; Brickman,P.; Hallar, B. and Norris, A (2009) 'Effects of Inquiry-based Learning on Students'Science Literacy Skills and Confidence' International Journal for the Scholarship of Teaching and Learning, 3(2) Article 16 [Online] Available at: https://doi.org/10.20429/ijsotl.2009.030216 (accessed: 30th Jan 2016)

Harackiewicz, J. M.; Barron, K. E.; Tauer, J. M. and Elliot, A. J. (2002) 'Predicting success in college: a longitudinal study of achievement goals and ability measures as predictors of interest and performance from freshman year through graduation' Journal of Educational Psychology 94(3); 562-575

James, P. (1998) 'Progressive development of deep learning skills through undergraduate and post-graduate dissertations.' Educational Studies 24(1); 95-105

Johnstone, K.M.; Ashbaugh, H. and Warfield, T.D. (2002) 'Effects of Repeated Pratice and Contextual-Writing Experiences on College Students' Writing Skills' Journal of Educational Psychology 94(2); 305-315

Jones, H. (2011) 'Are our students prepared for University?' Bioscience Education 18 [Online] Available at: http://www.bioscience.heacademy.ac.uk/journal/vol18/beej-184SE.pdf (accessed: 27 February 2013)

Kellogg, R.T. and Whiteford, A.P. (2009) 'Training Advanced Writing Skills: The Case for Deliberate Practice' Educational Psychologist 44 (4) [Online] Available at: http://dx.doi.org/10.1080/00461520903213600 (accessed: 30 January 2017)

Liu, O. L.; Frankel, L. and Roohr, K.C. (2014) 'Assessing Critical Thinking in Higher Edcation: Current State and Directions for Next-Generation Assessment' ETS Research Reports $\quad 1 ; \quad 1-23 \quad$ [Online] Available at: http://onlinelibrary.wiley.com/doi/10.1002/ets2.12009/full (accessed: $20^{\text {th }}$ April 2017)

Marbach-Ad, G. and Arviv-Elyashiv, R. (2005) 'What should life-science students acquire in their BSc studies? Faculty and student perspectives.' Bioscene 31(2); 11-15

Parkinson, J.; Jackson, L.; Kirkwood, T. and Padayachee, V. (2008) 'Evaluating the effectiveness of an academic literacy course: do students benefit?' Per Linguam 24(1); 11-29 [Online] Available at: http://dx.doi.org/10.5785/24-1-37 (accessed: 25 April 2013)

Rosenfeld, M.; Courtney, R. and Fowles, M. (2004) 'Identifying the writing tasks important for academic success at the undergraduate and graduate levels.' GRE Board Report no. 00-04 R ETS RR-04-42 [Online] Available at: https://www.ets.org/Media/Research/pdf/RR-04-42.pdf (accessed: 27 February 2014)

Saunders, V. and Zuzel, K. (2010) 'Evaluating employability skills: employer and student perceptions' Bioscience Education 15 [Online] Available at: www.bioscience.heacademy.ac.uk/journal/vol15/beej-15-2.pdf (accessed: 27 February 2013) 
Scott, J. (2005) 'Students' perceptions of skills acquisition in the undergraduate bioscience curriculum' Bioscience Education 6 [Online] Available at: www.bioscience.heacademy.ac.uk/journal/vol6/beej-6-1.pdf (accessed: 26 April 2013)

Stefani, L. A. J.; Tariq, V.-N; Haylings, D. J. A. and Butcher, A. C. (1997) 'A comparison of tutor and student conceptions of undergraduate research project work' Assessment and Evaluation in Higher Education 22(3); 271-288 